Бұл CC BY-NC-ND лицензиясы бойынша ашық жарыққа шыққан қол жетімді мақала (https://creativecommons.org/licenses/by-nc-nd/3.0/)

«Ғылымның өзекті мәселелері» - Халықаралық практикалық интернет- конференция материалдары

Басылым II, Қараша 2019

ISBN 978-601-323-144-0

https://doi.org/10.31643/2019.005

\author{
Айдана Оразаева \\ Абай атындағы ҚазҰПУ \\ E-mail: a_nurbolatovna@mail.ru \\ ORCID ID 0000-0001-5801-2459
}

\title{
Болашақ менеджерлерді бастауыш мектетпті басқару қызметіне даярлығын қалыптастырудың теориялық моделі
}

\begin{abstract}
Абстракт: Автор мақалада білім беру жүйесінде мәселелердің бірін зерттеген, соның бірі білім беру жүйесін басқару туралы қарастырады. Білім беру жүйесін бір моделге келтіру маңызды рөл атқарады. Әлеуметтік және кәсіби объектілерді тану мен қайта құрудың жетекші әдістерінің қатарына моделдеу жатады. Мақалада автор модель ұғымының мазмұнын және модельдеудің мәнін, оларды психологиялық-педагогикалық әдебиетте анықтауды қарастырып, модельдің құрылымдық элементтерін ұсынады. Зерттеудің нәтижесінде студенттердің басқару қызметіне біртұтас даярлық құрауыштарын қалыптастыру кезең-кезеңмен, модельде белгіленген міндеттер негізінде жүргізілетіндігі айқындалды. Анықталған проблеманың теориясы, оның ерекшеліктері, зерделенген психологиялық-педагогикалық әдебиеттерді талдау және бұрын жүргізілген диссертациялық зерттеулер негізінде теориялық көзқарастар негізделіп, ЖОО студенттерінің басқару қызметіне даярлығын қалыптастыру моделін ұсынады.
\end{abstract}

Тірек сөздер: Болашақ менеджерлер, мектетпті басқару, қалыптастыру, модель, компонент, студент.

Кіріспе. Қазіргі таңда білім беру жүйесінде айтарлықтай мәселелер бар. Соның бірі білім беру жүйесін басқару. Болашақ білім беру ұйымдары жетекшісінің басқару мәдениетін қалыптастырудың өзектілігі қазіргі әлеуметтік-экономикалық жағдай тұрғысынан оқу орнында орын алатын процестерді басқарудың балама педагогикалық жүйелерін енгізудің объективті қажеттілігімен анықталады. Басқару мәдениетін меңгеру- күрделі және ұзақ процесс, ол тұлғадан тек қана маңызды күш-жігерді ғана емес, сонымен қатар адамда белгілі бір нышанды талап етеді (Юнусова, А., 2019). Бұл мәселе тек Қазақстанда ғана емес, сондай-ақ алыс-жақын шетелдерде де зерттелуде. Мәселен, М. Арпентьева, «Разрушение университета: от «всесторонне развитой личности» к роботоустойчивому специалисту» зерттеу жұмысында білім беру процесі бұзылғандығын айтады (Арпентьева, М., 2018). Басқада зерттеулер білім беруде студенттердің құзіреттілігі төмендегендігін дәлелдейді (Kassymova, G., 2018; Atayeva M., Putro, N. H. P. S., Kassymova G., Kosbay S., 2019). Білім беру жүйесін бір моделге келтіру маңызды рөл атқарады. Әлеуметтік және кәсіби объектілерді тану мен қайта құрудың жетекші әдістерінің қатарына моделдеу жатады. Модель ұғымының мазмұнын және модельдеудің мәнін, оларды психологиялық-педагогикалық әдебиетте анықтауды қарастырайық. "Модель" сөзі француз тілінен аударғанда "үлгі"дегенді білдіреді.

"Модель-бейнелеу құралдарының кейбір схематизациясы мен шарттылығы кезінде заттың, процестің немесе құбылыстың бейнесін көрсететін көрнекі құрал немесе схема" (Словарь иностранных слов, 325 б. 1998). Кең мағынада модель абстракция деңгейіне дейін шындықты көрсететін сипаттама. Педагогикалық модель-бұл педагогикалық қызметтің моделі, онда күтілетін нәтиженің түпкі ойы көрсетілген, оның мәні айқындалған, күтілетін нәтижені жүзеге асыруға қажетті құралдар мен шарттардың сипаттамасы берілген, қызмет субъектілері көрсетілген (Михеев, В. И., 89 
б., 2002). Өз кезегінде, модельдеу процесі олардың үлгілеріндегі таным объектілерін зерттеу әдісі ретінде әрекет етеді.

Модельдегі ұйымдық-басқару қызметіне дайындықты қалыптастырудың негізгі категориялары оның бөліктерінің салыстырмалы Тәуелсіздігіне және сонымен бірге олардың функцияларының өзара байланыстылығына негізделген жүйенің негізгі қасиеті ретінде тұтастық ұғымы болып табылады. Модель мазмұнын құрылымдауға көмек берген жүйелік-құрылымдық тәсіл бізге өзара байланысты компоненттер мен олардың функцияларының біртұтас жиынтығын көрсетуге мүмкіндік береді ( Блауберг, И. В., 1973). Модельдің құрылымдық элементтері ретінде келесі сипаттамалар әрекет етеді: мақсаты, міндеттері, принциптері, кезеңдері, ұйымдастыру формалары, ұйымдастыру-басқару қызметіне студенттердің дайындық компоненттерінің қалыптасуын қамтамасыз ететін әдістер мен құралдар, интегративтік бағалау кешені ретінде өлшемдер мен көрсеткіштер жүйесі, нәтижесі ұйымдастыру-басқару қызметіне даярлықтың қалыптасқан деңгейі ретінде.

Зерттеу жұмысының өзектілігі. Таңдалған ғылыми тәсілдерге сүйене отырып, ұйымдастырушылық-басқару қызметіне дайындық макроқұрылымда біз екі функционалдық компонентті бөліп алдық: әлеуметтік және кәсіби. Ұйымдастыру-басқару қызметіне даярлықтың бөлінген компоненттері әмбебап және басқа да қызмет түрлеріне жатқызылуы мүмкін. Модель құрылымындағы субординация мен үйлестірудің негізгі сипаттамалары мен байланыстары екі векторды анықтайды: тік - қалыптастырушы және көлденең - келісуші (Төмендегі кестені қараңыз). Бұл модельде ЖОО студенттерінің ұйымдастыру-басқару қызметіне дайындығын қалыптастырудың мақсатты, іс жүргізушілік, мазмұнды және субъективті компоненттері, сондай-ақ осы дайындықты тиімді қалыптастыруға ықпал ететін педагогикалық жағдайлар кешені ашылады. Кейінгі кездердегі басқару аппаратының жұмыстарының сараптамасы мен ғылыми көздерін зерделеу мектепішілік басқарудағы кеңінен таралған төмендегідей мәселелерді атап көрсетті:

4 біріншіден: басшылардың басқару қызметіндегі кәсіби дайындықсыздығын;

\# екіншіден: басқарудың келешегінің және нәтижесінің бағытының жоқтығы;

— үшіншіден: жоспарлау тұтастай келешекті нәтижемен өзара байланыспайтын өзіндік іс- шараларды ұсынатынын;

\$ төртіншіден: көпшілік пен мұғалімдерді басқару үрдісіне қызықтыратын қызмет пен басшылар тарапынан өзіндік басшылық жүйесін құруға талпыныстың жоқтығы;

* бесіншіден: әкімшіліктің қызметі мәселелердің алдын алумен емес, керісінше күнделікті мәселелерді шешумен ғана шектелетінін көрсетті.

Біздің түсінігімізше мектепішілік басқару жүйесі - педагогикалық жүйенің бір саласы және әртүрлі деңгейлі басшылардың өзара бірлесіп әрекет етуін ұйымдастыратын құрылым, әдістемелік жүйенің іс-әрекетін қамтамасыз ететін және дамытатын бағыт, оқыту технологиясы мен педагогикалық қызмет арқылы басқару жүйесін құратын, қарым -қатынас пен басқарудың әдіс - тәсілі болып табылады. Басқару ұйымдастыру мен басқару жүйесінің үйлесімділігін, әдістемелік жүйесі моделінің келісімін, оқыту технологиясы және басқару жүйесінің моделін қамтамасыз етуі тиіс. Басқару қызметін моделдеуде білім беру ұйымдарының өзгешеліктері мен онда қолданыс табатын күтілетін маңызды ерекшеліктеріне, ішкі және сыртқы әлеуметтік ортаға байланысты қайшылықтарды талдауға бағытталуы тиіс.

Қызмет субъектілері ЖОО педагогтары мен студенттер болып табылады. Атап айтқанда, құрылымдық элементтер арасындағы өзара байланыс көрсетілген, оларға біз мыналарды жатқызамыз: жағдайды талдау және мақсат қою, жоспарлау, ұйымдастыру, бақылау.

Сонымен қатар, модельде студенттердің ұйымдастырушылық-басқару қызметіне дайындығын қалыптастырудың педагогикалық шарттары ашылады. Осылайша, модельдеу әдісі модельдің мәнін мазмұнды ашуға және оны графикалық түрде ұсынуға мүмкіндік береді. Сонымен, модельдің бірінші құрылымдық элементі ЖОО студенттерінің ұйымдастырушылық-басқару қызметіне дайындығын қалыптастыру ретінде анықталатын, кәсіби қызмет процесінде ұйымдастырушылық-басқарушылық кәсіби міндеттерді табысты шешуді негіздейтін мақсат болып табылады.

Жоғары оку орны студенттерінің ұйымдастыру-басқару қызметіне дайындығын қалыптастыру мақсаты, жоғары кәсіптік білім беру мазмұны қазіргі жағдайда мемлекет пен жұмыс берушілердің 
талаптарына негізделген, өйткені ұйымдастыру-басқару қызметіне дайындығы практикалық (кәсіби) ұйымдастыру-басқару қызметі процесінде көрініс табады және қызмет етеді.

Университеттің оку үрдісінде ұйымдық және басқарушылық іс-әрекеттерге даярлықты қалыптастыру міндеттері ретінде біз мыналарды қарастырамыз:

$>$ студенттердің ұйымдық және басқарушылық іс-әрекеттерге дайындығының психологиялық құрамын қалыптастыру;

$>$ студенттердің басқару қызметіне дайындығының мазмұнды компонентін қалыптастыру;

$>$ студенттердің басқару қызметіне дайындығын практикалық компонентін қалыптастыру (Келесі кестені қараңыз).

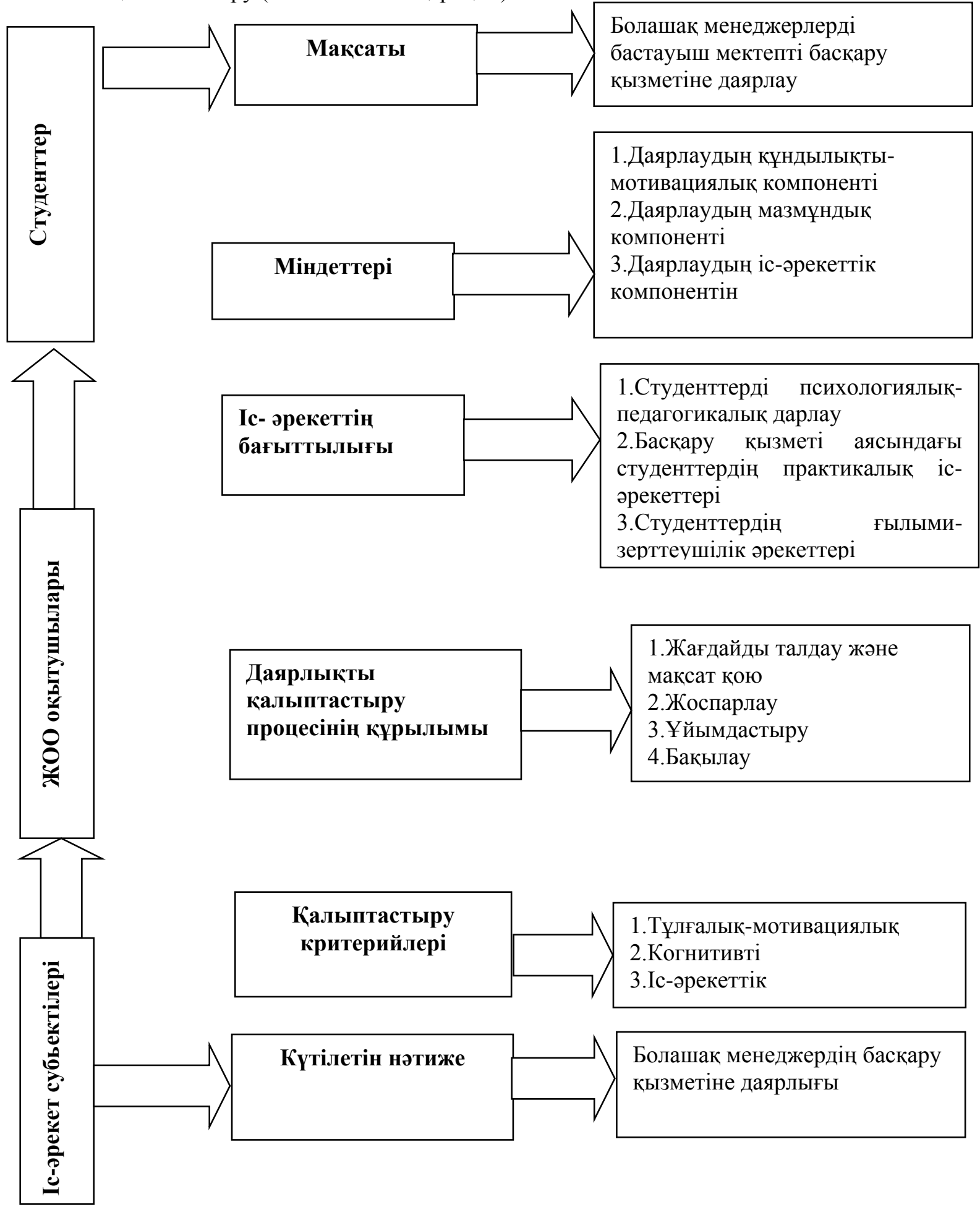

Кесте - Студенттердің басқару қызметіне даярлығын қалыптастыру моделі 
Зерттеу жұмысындағы мәселені шешу. Бөлінген міндеттерді шешу студенттердің басқару қызметіне дайындығын қалыптастыру стратегиясы негізделетін негізгі қағидаттармен анықталады:

$\checkmark$ жоғары білім беру мақсаттары мен мазмұнының әлеуметтік шарттылығы (мамандарды даярлау нәтижелерінің олардың кәсіби қызметінің нақты саласына қойылатын талаптарға сәйкестігі және олардың бәсекеге қабілеттілігін қамтамасыз ету);

$\checkmark$ жоғары білім беру мазмұнының құзыреттілік бағдарлылығы; интегративтік өзара ісқимыл субъектілігі.

Жоғары білім берудің мақсаты мен мазмұнының әлеуметтік шарттасу принципі студенттің жеке тұлғасын әлеуметтендіру және кәсіпқойландыру процестерінің өзара байланысын көрсетеді. Жоғары білім студенттің жеке тұлғасына бағытталған әлеуметтік құбылыс ретінде, маманның әлеуметтенуі мен кәсібилігінің маңызды функцияларын орындайды, оның жеке және кәсіби өзін-өзі анықтауының құралы ретінде әрекет етеді. Білім беру мазмұнының құзыреттілік бағдарлану принципі құзыреттілік тәсіл контекстінде оку пәндері бойынша жұмыс бағдарламаларының мазмұнын конструкциялау тиімділігінің негіздерін айқындайтын бастапқы ережелерді атап өту маңызды. Студенттер мен педагогтың өзара іс-қимылының субъектілік принципі студенттерді оқу үрдісінде белсенділік тасымалдаушы ретінде қарастырады. оқу және болашақ кәсіби қызметте өзінөзі жүзеге асыруға ұмтылуда мақсат таңдауға дайын екендігін ұғындыруда көрінеді. Бұл принцип студенттер мен педагогтың педагогикалық өзара іс-қимыл формаларының кешенін әзірлеуді көздейді, олар оқу сабағының мақсатына жетуді, кешенді дидактикалық міндеттерді шешуді қамтамасыз етеді. Ұйымдастырушылық-басқару қызметіне дайындықты сөз мағынасында үйрету мүмкін емес, өйткені құзыреттілік оқытудың ерекшелігі "дайын білім, біреу ұсынған білім емес, осы білімнің пайда болу жағдайлары байқалады" (Қазақстан Республикасының 12 жылдық білім беру тұжырымдамасы, 2006).

Педагогикалық өзара іс-қимыл формаларының ұжымдық және даралық принципі ұжымда, кіші топта, жеке және ұжымдық іс-әрекет процесінде жоғары білім мазмұнын меңгеру бойынша студенттердің іс-әрекетіне жағдай жасау үшін олардың ықтимал үйлесімін пайдалануды көздейді. Бұл жағдайда оқу қызметін ұйымдастыру нысандары фронтальды, жеке, топтық болуы мүмкін.

Біздің зерттеуіміз көрсеткендей, оқу сабақтарының кіріспе және қорытынды кезеңінде оқутанымдық тапсырмаларды қою сатысында өзара іс-қимылдың алдыңғы формасы қолданылады. Окужаттығу жұмысының алгоритмдік және өнімді деңгейінде ұйымдастырушылық-басқару қызметіне дайындығының бағдарлы негіздерін қалыптастыру кезінде қолданылатын топтық жұмыс түрі неғұрлым тиімді. Жеке форма дербес қызметті табысты қалыптастыруға мүмкіндік береді, оқытудың жеке траекториясын қамтамасыз етеді. Білім берудің гуманистік жеке-бағдарлы бағытына сүйене отырып, біздің көзқарасымызша, неғұрлым тиімді диалогтық қарым-қатынастың үлгісі болып табылады. Айтылған қағидаттарды қарау соңында алға қойылған мақсаттар мен міндеттерге қол жеткізу оларды кешенді қолдану кезінде мүмкін болатынын атап өту маңызды.

Зерттеудің нәтижесі. Студенттердің басқару қызметіне біртұтас даярлық құрауыштарын қалыптастыру кезең-кезеңмен, модельде белгіленген міндеттер негізінде жүргізіледі. Бұл кезеңдерде ұйымдастыру-басқару қызметіне даярлықтың психологиялық, мазмұнды және практикалық компоненттерін мақсатты қалыптастыру жүргізіледі.

Бірінші кезең студенттердің қызығушылығын, бейімділігін, әлеуметтік және кәсіби құндылықтарын, оқу үрдісінде құндылық бағдарларын игеру барысында қалыптастыру арқылы ұйымдастыру-басқару қызметіне уәждемесін қалыптастыруға бағытталған. Бұл кезеңде студент маманның кәсіби қызметінде құндылықты өзін-өзі анықтау субъектісі ретінде әрекет етеді. Бірінші кезеңнің нәтижесі: таңдаған мамандыққа бағыт беру; ұйымдастырушылық және басқарушылық қызметке даярлықтың құнды-мотивациялық компонентін қалыптастыру, ұйымдастырушылық басқару іс-әрекеттерін саналы түрде ынталандыру және келешектегі кәсіптік қызметтің әлеуметтікэкономикалық жағдайында өзін-өзі жүзеге асыру; болашақ басқарушылық іс-әрекеттердің маңызды аспектілеріне және кәсібі бойынша тұлғааралық қарым-қатынасқа оң көзқарас.

Ұйымдастыру-басқару қызметке даярлықтың екінші кезеңі функционалдық білімді, саналы дағдыларды, дағдыларды және іс-әрекеттерді, соның ішінде білім беру және кәсіби міндеттерді шешу кезінде өзара әрекеттесу және қарым-қатынас әдістерін меңгеруді меңгеруге бағытталған. Екінші 
кезеңнің нәтижесі студенттердің ұйымдастырушылық және басқарушылық іс-әрекеттеріне тұтас дайындығының маңызды компонентін қалыптастыру болып табылады.

Үшінші кезенде болашақ маманның ұйымдастыру-басқару қызметін жетілдіру, оның ұйымдастыру-басқару қызметіндегі әлеуметтік өзара іс-қимыл міндеттерін вариативті шешуге дайындығы міндеттері шешіледі; оқыту процесінде өзін осы қызметтің субъектісі ретінде сынақтан өткізу арқылы басқару қызметіне дайындықтағы іс-әрекет компонентінің жоғары деңгейіне қол жеткізу. Үшінші кезеңнің нәтижесі студенттердің ұйымдастырушылық-басқару қызметінде өзін-өзі жүзеге асыруға, әртүрлі факторлардың әсерін ескере отырып, әдеттегі жағдайларда өз қызметін бағалаумен және түзетумен байланысты басқарушылық міндеттерді шешуге, мәселелерді анықтауға және оларды шешу жолдарын табуға, кәсіби топтарда өзара қарым-қатынас жасай білуге дайындығы болып табылады.

ЖОО студенттерінің ұйымдастыру-басқару қызметіне дайындығын қалыптастыру моделін іс жүзінде жүзеге асыру ұйымдастыру-басқару қызметіне дайындық компоненттерін қалыптастыруды қамтамасыз ететін оқыту процесін арнайы ұйымдастыруды көздейді. ЖОО студенттерінің басқару қызметіне даярлығын қалыптастыруға келесі модельдің элементі болып табылатын педагогикалық жағдайлар кешенін жүзеге асыру ықпал етеді: студенттердің ұйымдастырушылық-басқару қызметіне жағымды мотивін қалыптастыру; ұйымдастыру-басқару қызметі туралы білім жүйесін қалыптастырудағы студенттердің кәсіби дайындығын пайдалану; студенттердің кәсіби дайындық барысында ұйымдастырушылық-басқару қызметі саласындағы практикалық іскерліктері мен дағдыларын қалыптастыру.

Студенттердің басқару қызметі саласында білімін және практикалық іскерлігін қалыптастыру барысында рефлексивті-бағалау қызметіне қосылуы. Біз бөлген шарттар бір мақсатты шешуге бағытталғандықтан және өз жиынтығында қисынды өзара байланысты болғандықтан, бұл олардың кешен болып табылатындығын дәлелдеуге негіз болады. Модельдің ажырамас бөлігі ретінде студенттердің басқару қызметіне дайындығы компоненттерінің қалыптасуының критериилері мен көрсеткіштері жүйесі болып табылады. Біз басқару қызметіне әзірліктің қалыптасу өлшемдеріне мыналарды жатқыздық: ұйымдастырушылық-басқарушылық қызметке мотивациялық-тұлғалық бағыттылығы, ұйымдастырушылық-басқарушылық қызметке когнитивтік бағыттылығы және ұйымдастырушылық-басқарушылық қызметке қызметтік бағыттылығы.

Ұйымдастыру-басқару қызметіне мотивациялық-тұлғалық бағыттылығына студенттердің таңдаған мамандығы шеңберінде ұйымдастыру-басқару қызметіне деген жағымды мотивтері мен қызығушылығының болуы кіреді. Басқару қызметіне деген когнитивтік бағыттылық- теориялық білім мен ұйымдастырушылық-басқару қабілеттерінің көлемін қамтиды. Басқару қызметіне іс-әрекеттік бағыттылық- практикалық білік пен дағдының қалыптасу деңгейін, жағдайға барабар әсер ету тәсілдерін қолдана білуді, адамдармен қарым-қатынас жасауды, рефлексивті дағдыларды меңгеруді қамтиды.

Қорытынды. Басқару қызметіне мотивациялық-тұлғалық бағыттылық, когнитивтік және ісәрекеттік бағыттылық студенттердің ұйымдастыру-басқару қызметіне дайындығының критерийлері болып табылады. Егер студенттерде барлық компоненттер қалыптасса, онда басқару қызметіне тұтас дайындық қалыптасқаны туралы қорытынды жасауға болады. ЖОО студенттерінің қазіргі жағдайда басқару қызметіне даярлығын қалыптастыру мәселесін біз жоғары білімнің маңызды міндеттерінің біріне жатқызамыз. Әлеуметтік және қоғамдық өмірдегі өзгерістер саналы таңдау жасай алатын, шешім қабылдай алатын және олар үшін жауапты, басқа адамдармен тиімді өзара іс-әрекет жасай алатын, ұжымға басшылық жасай алатын еркін және жауапты адамның басты құндылығы ретінде анықталады.

Жоғарыда айтылғандарды қорытындылай келе, анықталған проблеманың теориясы, оның ерекшеліктері, зерделенген психологиялық-педагогикалық әдебиеттерді талдау және бұрын жүргізілген диссертациялық зерттеулер негізінде теориялық көзқарастар негізделіп, ЖОО студенттерінің басқару қызметіне даярлығын қалыптастыру моделін ұсынады, бұл ЖОО-да оқыту процесінде мәлімделген мәселе бойынша тәжірибелік-эксперименталды жұмысты ұйымдастыруға және жүргізуге мүмкіндік береді. 
Aidana Orazayeva

Abai KazNPU, Kazakhstan

E-mail: a_nurbolatovna@mail.ru

ORCID ID 0000-0001-5801-2459

\title{
Theoretical model for Formation of Future Managers' Training in Primary School Management
}

\begin{abstract}
The article examines one of the educational issues, one of which is the management of the education system. An education system plays an important role. The most advanced methods of recognition and reconstruction of social and professional objects are modeling. In the article, the author considers the content of the concept of model and the meaning of modeling, identifying them in psychological and pedagogical literatures, and presents the structural elements of the model. As a result of the research, it was determined that the formation of uniform training components for students' management activities will be carried out on the basis of the model tasks. The theory of the detected problem is based on theoretical approaches based on the analysis of studied psychological and pedagogical literatures and its previous dissertation research, and provides a model for the preparation of students' leadership in management.
\end{abstract}

Keywords: Future Managers, School Administration, Formation, Model, Component, Student.

Бұр мақалаға сілтеме: Оразаева, А., (2019) Болашақ менеджерлерді бастауыш мектетпті басқару қызметіне даярлығын қалыптастырудың теориялық моделі. «Ғылымның өзекті мәселелері» - Халықаралық практикалық интернет- конференция материалдары / Materials of International Practical Internet Conference "Challenges of Science”. ISBN 978-601-323-144-0. Басылым II, 2019. Бет: 32-37. https://doi.org/10.31643/2019.005

\section{Пайдаланылған әдебиеттер тізімі}

[1] Aksarina, I. Y., Dossayeva, S. K., Kosov, A. V., Stepanova, G. A., Akentyeva, I. Y., Brovkina, S. N., Kozhedyorov, A. I., Arpentieva, M. R. , Khoteeva, R. I., Kassymova, K. G. (2019). Foresight innovations in educational systems in the BRICS countries. Bulletin of National Academy of Sciences of the Republic of Kazakhstan. ISSN 1991-3494. 4(380), 123-131. https://doi.org/10.32014/2019.2518-1467.100

[2] Arpentieva, M. Destruction of the University: from a "Comprehensively Developed Personality" to a "Robustly Robust Specialist” (Арпентьева, М. Разрушение университета: от «Всесторонне развитой личности» к «робото утойчивому специалисту»). Challenges of Science (In Russian), 2018. https://doi.org/10.31643/2018.002

[3] Arpentieva M.R., Kassymova G., Kenzhaliyev O., Retnawati H., Kosherbayeva A. (2019) Intersubjective Management in Educational Economy. Materials of International Practical Internet Conference "Challenges of Science". ISBN 978-601323-144-0. Issue II, 2019. Page 24- 31. https://doi.org/10.31643/2019.004

[4] Atayeva M., Putro, N. H. P. S., Kassymova G., Kosbay S. (2019) Impact of reading on students' writing ability. Materials of International Practical Internet Conference "Challenges of Science". ISBN 978-601-323-144-0. Issue II, 2019. Page 513. https://doi.org/10.31643/2019.001

[5] 68. Блауберг И. В. Становление и сущность системного подхода/ И. В. Блауберг, Э. Г. Юдин. - М.: Наука, 1973. $-191 \mathrm{c}$.

[6] 2 Қазақстан Республикасының 12 жылдық білім беру тұжырымдамасы. ҚР Білім және ғылым министрінің 2006 жылғы 4 қаңтардағы №1 Бұйрығымен бекітілген.

[7] Kassymova, G. (2018). Competence and its implications. Challenges of Science. Conference: International Practical Internet Conference "Challenges of Science", November 2018. P.366-368. https://doi.org/10.31643/2018.063

[8] 67. Михеев В. И. Методы измерения в педагогических исследованиях/ В. И. Михеев, А. Ю. Потапова.- М.: Издательский центр АПО, 2002.- 48 с.

[9] 66.Словарь иностранных слов.- 15-е изд., испр.- М.: Рус.яз., 1998.- 607 с.

[10] Suleimen, S., Orazayeva, A., (2019) Informational cultural description of the future teacher-manager in the education system. Materials of International Practical Internet Conference "Challenges of Science". ISBN 978-601-323-144-0. Issue II, 2019. Page 14 - 19. https://doi.org/10.31643/2019.002

[11] Юнусова, А., (2019) Болашақ менеджерлердің басқару мәдениетін қалыптастыру. «Ғылымның өзекті мәселелері» Халықаралық практикалық интернет- конференция материалдары / Materials of International Practical Internet Conference "Challenges of Science". ISBN 978-601-323-144-0. Басылым II, 2019. Бет: 20 - 24. https://doi.org/10.31643/2019.003 